\title{
Women's Decision-Making Autonomy and ICT Utilization on Access to Antenatal Care Services: Survey Results From Jinja and Kampala Cities, Uganda.
}

Hasifah K. Namatovu, Ph.D., Corresponding Author, Department of Information Systems, Makerere University, Kampala, Uganda.hknamatovu@,cit.ac.ug

Tonny J. Oyana, Ph.D., Geospatial Data and Computational Lab, Makerere University, Kampala, Uganda.toyana@,cit.ac.ug

Jude T. Lubega, Ph.D., Department of Computing and Engineering, University of Technology and Management, Kampala,Uganda.judlub@gmail.com

\section{Abstract}

There is growing evidence in Uganda that the non-attendance of antenatal care is largely influenced by the lack of decision-making autonomy, inadequate information and poor services offered in health facilities. Although previous studies have examined barriers and facilitators of antenatal care, a few of them have investigated the extent of decision making autonomy and ICT adoption among expectant mothers. A cross sectional design through focus group discussions and survey questionnaires was used to collect data. Three hundred and twenty households were randomly sampled in Kampala and Jinja districts. The Chi-square tests $\left(\chi^{2}\right)$ for independence to analyze group differences among women's socio-demographic characteristics and decision-making autonomy was used. Inclusion criteria included respondents aged 18 and 50 years, completion of primary school education, expectant mothers and mothers who gave birth two years prior to the study. A hundred and sixty-four respondents participated in this survey. About 59.5\% of women lacked decision making autonomy. Midwives (37.6\%) and village health teams (35\%) were a major source of antenatal care information, and $49.5 \%$ of expectant mothers lacked ANC information. Ninety percent (90\%) of mothers did not use any form of ICT's to enhance their decisions yet $79 \%$ possessed mobile phones. We observed a strong association between antenatal care decision-making autonomy and women with higher education $\left(\chi^{2}=8.63, \rho=0.035\right)$, married $\left(\chi^{2}=4.1, \rho=0.043\right)$ and mature $(36-50)\left(\chi^{2}=8.81, \rho=0.032\right)$. The main findings in this study suggest that ICT adoption and decision making autonomy among expectant mothers is still low and less appreciated. Control measures and interventions should be geared towards empowering women to influence their decisions.

Key words: ICT Adoption; Urban health; Antenatal Care; Women Health 


\section{Background}

Maternal mortality is still high and remains a big public health issue among countries situated in SubSaharan Africa [1, 2]. It is estimated that 358,000 women (830 deaths everyday) died worldwide in 2008, as a result of preventable causes related to pregnancy and childbirth [3]. This is more than 34 women per hour. Of these, 99\% occurred in developing countries. Regionally, Sub-Saharan and South Asia accounted for $87 \%$ of the global maternal deaths [4]. In Uganda an estimated 16 women die from giving birth every day; on average this is one death every hour and a half, and nearly 6,000 every year $[5,6]$. High maternal mortality is attributed to lack of access to modern family planning, low awareness of danger signs of pregnancy/labour [2,7]. Furthermore, the inability of some pregnant women to attend antenatal care (ANC), deliver in a health facility and facility location has aggravated the situation [7, 8].

Many of these deaths are preventable once mothers get adequate maternal access and emergency obstetric care (EmOC) [9]. The most critical intervention of maternal mortality is, i) participating in ANC, ii) delivery by skilled birth attendant (SBA), iii) access to EmOC, and iv) access to family planning services $[10,11]$.

ANC establishes the first contact with health facilities and it is highly premised that mothers who have attended at least more than one ANC are more likely to give birth with a help of a SBA [12]. ANC provides an avenue for mothers to receive information and guidance on safe childbirth and help prevent, detect and alleviate health problems that affect mothers and babies during pregnancy $[7,13,14]$. WHO recommends every pregnant woman to visit a health facility at least four times during pregnancy [15]. Despite numerous efforts to have women attend ANC in Uganda, only $47 \%$ attended the recommended four visits while $58 \%$ delivered in a health facility $[16,17]$. However, little information and knowledge is available on the barriers and facilitators of ANC in rapidly developing urban centers. The purpose of this study is to investigate the extent of ICT adoption and decision making autonomy in influencing access to ANC in Uganda. 


\section{Methods and Materials}

\section{Study Setting and Sampling}

Kampala and Jinja population represent a typical urban population that is rapidly growing with high demand for high-quality ANC services, and provides a representative sample to understand urban health among women. A mixed method (quantitative and qualitative) approach was used to collect and analyse the evidence received from respondents. Through purposive and stratified random sampling techniques, this study ensured that expectant mothers and mothers who gave birth two years prior to the study were properly drawn from sparsely and densely populated neighbours in Kampala and Jinja districts. The use of these two sampling techniques yielded a representative subset of all women receiving ANC. The sample was used to ascertain the type and nature of decisions that mothers routinely engage in while pregnant. Inclusion criteria included respondents aged between 18 and 50 years old, completion of primary school education, expectant mothers and mothers who gave birth two years prior to the study.

\section{Study Design}

A cross sectional design was used to collect baseline and thematic data on the study population using a two-step approach. The sample population was drawn from Walukuba, Mpumudde, Mengo Kisenyi and Kasubi Kawaala parishes situated in Jinja and Kampala district covering a period from January to April 2015. The first step involved the creation of baseline data through interviewing 35 expectant mothers from 59 randomly sampled households. Baseline data was used to understand the characteristics of the sample population and this informed an in-depth study. In Walukuba, a total of 8 mothers were interviewed, $\mathrm{N}=3$ were pregnant and $\mathrm{N}=5$ were mothers with children below two years. In Mpumudde, 6 women were interviewed, $\mathrm{N}=2$ were pregnant and $\mathrm{N}=4$ were mothers with children below two years. In Mengo Kisenyi, 10 participated, $\mathrm{N}=2$ were pregnant and $\mathrm{N}=8$ were mothers with children below two years. In Kasubi Kawaala, 11 participated, $\mathrm{N}=3$ were pregnant and $\mathrm{N}=8$ were mothers with children below two years. Baseline studies are important for establishing key priority areas of the study and provide quantitative information on the current population status [18].

The second step involved the collection of thematic data through a survey questionnaire. Using baseline data, a survey questionnaire was formulated based on three major themes (demographics; source and 
type of information that aids decision making, decision making autonomy and barriers of access to ANC services; and uptake of ICT). A survey questionnaire with open-ended and closed-ended questions was pre-tested on women residing in Lubya zone, which is outside the surveyed area.

A stratified random sample of 320 households located in different strata in Jinja and Kampala was used to administer 350 survey questionnaires. The sampling took place in three phases; defining the characteristics of study population and partitioning it into households, choosing the sample size based on different strata (a $20 \mathrm{~m}$ to $30 \mathrm{~m}$ distance between two households, distance to nearest ANC service point and female demographics); and randomly selecting the first household to administer the survey questionnaire.

Two trained research assistants together with one female local resident guided the house to house distribution of questionnaires. Before the survey, they were trained on the primary objective of this study, ethical code of conduct, temperament, especially where respondents were rude and nonresponsive. Each sampled household was approached by a research assistant to seek consent from the household head and determine whether there was a pregnant woman or a mother with a child below two years old present. Households that were near the main road or a trading centre were used as a starting point, and subsequent households were selected from the sampling list. This whole process took an average of 48 days.

Survey questionnaires were collected after one week, and women who could not comprehend the content of the questionnaire were guided by the interviewers in a verbal one-on-one interaction. In some cases, these had to be translated in local languages. However, use of ANC cards to capture the number of times a woman had attended ANC, parity and their age was minimally used because most of them, especially those that had given birth prior the survey had either lost or discarded the cards.

In the qualitative study, 10 pregnant women, 5 from each district were carefully selected to participate in the focus group discussion that lasted approximately 80 minutes.

\section{Data analysis}

All data was coded, processed and analyzed using IBM SPSS Statistics Version 25 (New York, USA). Analysis to test the association of socio-demographic and decision-making autonomy was achieved using Chi-square tests $\left(\chi^{2}\right)$. 
Qualitative responses were analyzed using conventional content analysis, which involved reading data repeatedly to try and identify common patterns. Any patterns identified from the written statements, oral or audio data were encoded.

\section{Ethical Approval}

Written consent to conduct this survey was sought from Kampala City Council Authority. Further approval was orally sought from the local council leaders. All women who participated gave a verbal consent while others sought consent from their spouses.

\section{Results}

\section{Descriptive results}

Socio-demographics of the study population is summarised in the Table 1 . The total of 320 households were visited, 145(45.4\%) in Jinja and the rest in Kampala. Thirty three percent of the respondents had completed primary school education, $36.2 \%$ secondary, $11.7 \%$ vocational while $19 \%$ had done university. At the time of the study, 42(25.6\%) women were pregnant while 122(74.4\%) were mothers who had given birth two years prior the study. Two fifth (39.5\%) of the respondents had given birth to two children, $40(24.4 \%)$ had three, $26(15.9 \%)$ had one, $21(12.8 \%)$ had more than four while $12(7.3 \%)$ had no child but were pregnant. Of the households visited, three quarters (75.9\%) were headed by men; $24.1 \%$ by women; $151(47.3 \%)$ had a $5 \mathrm{~km}$ or more distance from a public health facility while $169(52.7 \%)$ from a private health facility.

It is also indicated that half of these respondents in this age bracket had given birth to at least one child, many of these (35.3\%) having two or more children (See table 2). Further analysis indicates that out of those that had completed primary and secondary education, $25.7 \%$ and $28.7 \%$ had given birth to two or more children respectively.

Results in table 3 indicate that more than three quarters $(80.5 \%)$ of the respondents were married, majority of these ranging between $18-25$ years.

The Pearson's Chi-square results presented in table 4 indicated that there was a significant association between age and parity $\left(\chi^{2}=38.15, \rho<0.001\right)$, age and education $\left(\chi^{2}=35.12, \rho<0.001\right)$, decision making 
autonomy and education $\left(\chi^{2}=8.63, \rho=0.035\right)$, decision making autonomy and age $\left(\chi^{2}=8.81, \rho=0.032\right)$, decision making autonomy and marital status $\left(\chi^{2}=4.1, \rho=0.043\right)$. However, analysis shows that there was no association found between education and parity $\left(\chi^{2}=17.8, \rho=0.122\right)$, age and marital status $\left(\chi^{2}\right.$ $=4.9, \rho=0.179)$, education and marital status $\left(\chi^{2}=3.14, \rho=0.371\right)$, decision making autonomy and parity $\left(\chi^{2}=4.29, \rho=0.368\right)$.

\section{Antenatal Care and Decision-Making Practices}

\section{Major source of antenatal care information}

Thirty seven percent of women relied on midwives for ANC information although more than half $(24.8 \%)$ of these were from Kampala. Slightly less than one third $(35 \%)$ depended on village health teams (VHT) majority (22.9\%) were from Jinja. Nineteen percent depended on peer mothers, $4 \%$ depended on family and friends while $3 \%$ depended on none other than themselves.

\section{Decision-making autonomy}

Fifty nine percent of the mothers did not have the autonomy to influence their ANC decision making with majority (34.4\%) coming from Jinja.

\section{Why mothers did not make their antenatal care decisions?}

Lack of knowledge about ANC (49.5\%), husbands being the sole financial providers (32\%), others did not know (12.4\%), culture (1\%) and lack of self-trust (1\%).

\section{Use and Uptake of ICT}

Prior to the study, seventy nine percent of the mothers (see figure 2) owned mobile phones although more than three quarters (90\%) had never used any ICT's for ANC (see table 5). Almost ninety percent $(89.9 \%)$ of the mothers were not using any known ICT's for their ANC practices. However, a few of those that used ICT's in ANC, $8 \%$ used mobile phones while 1.9\% used computers (table 5). Some of the ICT services that were used to access ANC were SMS (2.4\%), instant messages (4.3\%), voices services (2.4\%) (Figure 3). Findings shown in figure 4 indicate that apart from voice and SMS, mother's used mobile phones for WhatsApp (56.7\%), Facebook (36.6\%), mobile money (5.5\%), twitter (0.6\%) and others like Instagram (0.6\%). In figure 5, mothers indicated several barriers that limited the uptake of ICT services in supporting their decisions and these included, the high cost of data and voice services 
(15.2\%), poor quality internet services (5.5\%), lack of skills to use ICT tools and services $(42.1 \%)$, limited knowledge on the importance of ICT in ANC (35.4\%) and the lack of integrated services (1.8\%).

\section{Qualitative Data}

Ten women were randomly selected from the 164 and engaged further in a focus group discussion (FGD) for approximately 80 minutes. Purpose was to ascertain the nature and types of decisions that mothers routinely engage in while pregnant. The question that guided the discussion was: 1) what decisions do you usually make while pregnant? Mothers could not straight away point out the different types of ANC decisions. However, basing on the different opinions, and after a word by word thorough scrutiny and deductions from their responses, the six categories of decisions summarized below were arrived at: facility-based decisions, care decisions, nutrition, birthing, attendant-based and lifestyle decisions.

Responses from mothers are ranked according to the frequency a particular response was mentioned during the FGD. This is followed by an explicit explanation of the mothers' opinions and experience. Excerpts from the FGD and anecdotal evidence were integrated in the narrative to give a reader a clear perspective of the mothers' experience. Below is a summary of responses from mothers followed by an elaborative narrative of their experience.

When asked about the types of decisions they regularly engage in while pregnant, all participants agreed to have at least engaged in two of the decisions summarized in the list above. Except for the six, the rest acknowledged participating in facility-based decisions which entailed "where to go for $A N C$, emergency care, delivery, newborn care or postnatal care". One participant offered a statement that echoed the sentiments of others; this statement sums up the ease with which some mothers made facility-based decisions.

"Every time I wanted to go to hospital for ANC, I just informed my husband and he gave me money for transport". 
Single mothers made their choice of hospitals as one mother narrated "...I am a single mother, so I decide which hospital to go to ...". However, the choice of a health facility was generally influenced by the "distance", "cost of services" and "the type of services offered" as narrated by some mothers.

Other mothers cited participating in care decisions which, to our understanding, meant ANC decisions and emergency obstetric care (EMOC) decisions. More than half of the mothers agreed to not participating in these decisions. One mother particularly acknowledged being in charge of "where, when and what ANC services they sought for". Almost all (9 out of 10) mothers agreed not to participate in EmOC decisions stating that "...they sometimes did not know what constituted an emergency..." others had "...domineering spouses....” while others “.....thought it was normal to experience certain conditions while pregnant..." so these factors delayed the mothers' decision to seek care.

When engaged further, more than half ( 7 out of 10) of the mothers acknowledged deciding what to eat, when to eat, how and the quantity. We collectively termed these as nutrition decisions. The rest acknowledged not deciding their meals, and one mother in particular described this as a "husband's right", in her narration she stated "the husband is the head of the family and he provides the money to buy the food, so he has full autonomy over what we eat.

Contrary to this statement, one mother in her statement that supported the opinions of others, noted that “...it's my role as a home maker to decide the best meal to have because my condition (pregnancy) dictates what meal we shall have in a given day...." 
At the time of delivery, many mothers (8 out 10$)$ acknowledged deciding on how they would deliver. We referred to these decisions as "birthing decisions". Of the eight mothers, 6 opted for normal delivery
In my third trimester, I start using local herbs (commonly known as emmumbwa) to soften my pelvic bones because I cannot accept to be cut (referring to a C- section). I try as much as possible during labour to have the baby normally.

while the 2 went with caesarean section. A C-Section delivery was not an option because of the cost implication such that many mothers opted for normal delivery even when it was eminent that normal delivery wasn't possible. The opinions of the different participants are captured in the comments of one of the participants who narrates:

Expectant mothers consider normal birth delivery as an act of valor. Some mothers especially from urban and affluent families to opted for SBA. We referred to these decisions as attendant-based decisions. Except the 6, 4 mothers had their personal gynecologists. This was attributed to the fact that these mothers did not want to go to general hospitals because in their opinion, “.... they were too congested..." or “...care providers were insensitive and rude...", or ".services were poor...”. One of the mothers, in her opinion emphasized "the lack of empathy with most care providers in these general hospital..." and thus chose a private care provider even if it meant "spending a lot more than usual". Mothers that could not afford a private gynecologist, went to general hospitals and had no choice of who was to assist them during delivery. One mother in particular stated "... whoever I find in hospital is the one who helps me in delivery..." and another mother supplemented "...I have no choice on a midwife to assist me because one is lucky to find one who is willing to help you..."

Participants indicated that they engaged in exercising, yoga, swimming, walking while pregnant. Those who drank alcohol and smoked prior to conception stopped when they conceived while others (2 out of 5) indicated taking folic acid before conception. In this study, we referred to these as lifestyle decisions. A few mothers pointed out their urge to stay healthy for the sake of their unborn babies. While one participant narrated that "yoga relaxes her" another mother admitted to "...quitting smoking the moment she discovered she was pregnant..."

The common threads from the qualitative data collected from expectant mothers is summarized below:

- Key factors that determine their choice of health care center are distance, cost and service type. 
- Barriers to ANC decisions are spouses and inadequate knowledge on what constitutes an emergency.

- Nutrition decisions were positively reviewed in their favor due to direct home involvement in meal preparations.

- Normal delivery was the preferred method of delivery.

- SBA was mainly determined by the care providers, especially by mothers with prior experience in a general hospital. A small number of mothers who could afford a private specialist chose gynecologists as their preferred SBA.

- Staying healthy and fit was important for a few mothers and their unborn babies.

\section{Discussion}

This study has four major findings: 1) the lack autonomy to influence ANC decisions for majority of mothers, 2) the general lack of ANC information, 3) the fundamental role of midwives and VHT's as major sources of ANC information, and 4) the limited use of ICT's especially mobile phones to aid decision making.

Our findings are consistent with previous studies $[16,19,20,21,22,23,24,25,26,27,28,29,30,31$, 32, 33]. This study found a strong association between ANC decision-making autonomy and women with higher education $\left(\chi^{2}=8.63, \rho=0.035\right)$, married $\left(\chi^{2}=4.1, \rho=0.043\right)$ and mature $(36-50)\left(\chi^{2}=\right.$ $8.81, \rho=0.032$ ); educated women were more likely to influence their decisions compared to their less educated counterparts. On average, majority of the respondents in both regions had less decisionmaking autonomy especially women from Jinja. Generally, spouses, midwives and VHT's greatly influenced mother's ANC decisions. This supports previous studies in Ghana and Bangladesh that noted husbands, mothers-in-law, family and community members being principal decision makers especially in cases of EmOC [21, 23]. This over-dependence on VHT's for ANC decisions among less educated mothers is a barrier to ANC access. Lack of knowledge and information was the major hindrance to participation to decision making, which was also emphasized in the WHO report as one of the reasons why women in the Sub-Saharan region did not access ANC services [32]. Spouses dictated when and where to do routine ANC, where to go in case of an emergency, delivery and sometimes influenced the 
diet of their wives because they provided therefore exercising power, as a house head was unquestionable [33]. Also, care providers largely influenced how women were to give birth.

Suffice to say, the lack of decision-making autonomy to seek care was seen in almost half of the respondents. This can be corroborated in other similar studies [23, 31]. The lack of autonomy coupled by the lack of information, money, poor services and long distances to health facilities culminated to the non-attendance of ANC. These inhibiting factors were also common in a study conducted in Dokolo, Rwashamaire, Kayunga and Budadiri districts in Uganda [24]. During pregnancy, mothers interact with different people like VHT's, midwives, spouses, peer mothers among others. This interaction indicates that mothers don't make decisions in solitude. However, mother's decision-making autonomy should be enabled, not crippled. An interesting finding which has not been reported elsewhere was the different types of decisions mothers routinely engage in which include; facility-based, nutrition, lifestyle, birthing, attendant and care-based decisions.

Expectant mothers relied more on midwives and VHT's for information and other maternal health related services. This finding is consistent with another study [21]. However, in our study, expectant mothers in Kampala relied heavily on midwives for ANC information while those in Jinja depended more on VHT's. This can be corroborated by previous studies conducted in Kamuli, Pallisa and Kibuku districts where the major source of information for maternal and neonatal health were VHTs [19]. Peer mothers also played a fundamental role of providing ANC information to expectant mothers especially in Jinja.

Fifty percent of expectant mothers who participated in this study acknowledged some information that was relevant in their routine ANC decision making practices. However, more than two-fifth demonstrated a clear lack of knowledge on ANC issues, which was consistent with previous studies $[22,30]$. This shows that mothers are ignorant of their ANC information needs. This was more evident among women from Jinja. The general lack of knowledge is consistent with other studies conducted in Busia, Gulu and South-Western [16, 25, 28].

Notably, findings indicated that majority of the women were not using ICT's in their routine ANC decision making practices even though many had mobile phones. A few of the mothers that managed 
to use ICT's for ANC relied on mobile phones. Apart from voice services, mothers largely used their mobile phones for social media services like WhatsApp and Facebook for social interactions but not maternal issues. This relates to a similar study conducted in Ghana [27]. Although the adoption of ICT services in enhancing access and use of ANC services was still very low, which is consistent in other studies [25], a few mothers used voice, SMS and instant messages in their daily ANC routine practices with either midwives or VHT's. The major reasons that inhibited mothers' use of ICT's in their routine ANC practices included the lack of technical skill to use the technologies, the limited knowledge of the capabilities of ICT's and the high data costs, which is consistent with other studies [20,29].

\section{Implications}

There are two implications for this study. Firstly, the need to use the data and knowledge developed to enhance ICT use in ANC decision making practices among expectant mothers in Uganda. The decision to utilize ANC services varied greatly along social-economic and demographic factors. It was found out that expectant mothers especially those from rural settings were less aware of ANC information needs and largely depended on their spouses, VHT's and peers for information and decision making.

Secondly, to create favorable policies that encourage expectant mothers to seek early ANC, especially in cases of emergency, to reduce the risk of maternal and/or neonatal deaths.

Findings suggest that the lack of information and confidence among mothers, husband's financial support and cultural factors largely contributed to the low decision-making autonomy. This should be mitigated through health education awareness programs.

\section{Recommendation and Future Direction}

To improve on maternal health outcomes, there's a need to empower expectant mothers to make decisions to seek care from skilled birth attendants. Additional research is required to determine the effectiveness of ICT services to support ANC with goal of closing the gap between the service providers and consumers. Our findings show a strong link between expectant mothers and midwives/VHT. Interventions to strengthen the interaction and synergy between mothers and these stakeholders to 
enable seamless exchange of information and collaboration may create an avenue for mothers to have a certain degree of autonomy over their decision-making practices.

\section{Acknowledgment}

We would like to extend our sincere gratitude to the staff, management and colleagues of Kampala City Council Authority and Makerere University College of Computing and Information Sciences, Kampala, Uganda. Special thanks to our research assistants, respondents and community health workers who provided critical data and support through their participation

\section{References}

1. Serbanescu F, Goldberg HI, Daniel I, Wuhib T, Marum L, Obiero W, McAuley J, Aceng J, Chomba E, Stupp PW, Conlon CM. (2017). Rapid Reduction of Maternal Mortality in Uganda and Zambia Through the Saving Mothers, Giving Life Initiative: Results of Year 1 Evaluation. BMC Pregnancy and Childbirth. 17:42

2. Girum T and Wasie A. (2017). Correlates of Maternal Mortality in Developing Countries: An Ecological Study in 82 Countries. Maternal Health, Neonatology and Perinatology.

3. World Health Organization. (2016a). WHO Recommendations on Antenatal Care for A $\begin{array}{llll}\text { Positive Pregnancy } & \text { Experience. } & \text { Retrieved }\end{array}$ http://apps.who.int/iris/bitstream/10665/250800/1/WHO-RHR-16.12-eng.pdf Accessed on $\underline{4 \text { th-Sept-2017 }}$

4. World Health Organization. (2010). Trends in Maternal Health, 1990 to 2008 Estimates developed by WHO, UNICEF, UNFPA and World Bank. Geneva: 3:19.

5. Nassaka F. (2016). What if more mothers are dying? The Independent Newspaper. 5 Sept 2016. Available: https://www.independent.co.ug/ugandan-mothers-dying/ Accessed 02 April 2018

6. Kabayambi J. (2014). Global Trends in Maternal Mortality: How Does Uganda Fare? Center for Health, Human Rights \& Development. 
7. Nieburg P. (2012). Improving Maternal Mortality and Other Aspects of Women's Health. The United States' Global Role.

8. Human Development Report. (2011). United Nations Development Program.

9. Lewis G. (2008). Maternal Mortality in the Developing World: Why Do Mothers Really Die?

Obstetric Medicine 2008; 1: 2-6.

10. World Health Organization. (2016b). WHO Recommendations on Antenatal Care for A $\begin{array}{llll}\text { Positive Pregnancy } & \text { Experience. } & \text { Retrieved }\end{array}$ http://apps.who.int/iris/bitstream/10665/250800/1/WHO-RHR-16.12-eng.pdf Accessed on $\underline{4 \text { th-Sept-2017 }}$

11. Atekyereza PR. \& Mubiru K. (2014). Influence of Pregnancy Perception on Patterns of Seeking Care among Women of Reproductive Age of Masaka District, Uganda. Tanzania Journal of Health Research, Vol. 16, No. 4

12. Guliani H, Sepehri A, \& Serieux J. (2012). What Impact Does Contact with the Prenatal Care System Have on Women's Use of Facility Delivery? Evidence from Low-Income Countries. Social Science and Medicine 74, no.12 (June): 1882-1890.

13. Kuhnt J. \& Vollmer S. (2017). Antenatal Care Services and its Implications for Vital and Health Outcomes of Children: Evidence from 193 surveys in 69 Low-Income and MiddleIncome Countries. BMJ Open 2017;7: e01722

14. Cumber SN, Diale DC, Stanley EM, Monju N. (2016). Importance of Antenatal Care Services to Pregnant Women at the Buea Regional Hospital Cameroon. Journal of Family Medicine and Health Care. Vol. 2, No. 4, 2016, pp. 23-29. doi: 10.11648/j.jfmhc.20160204.11

15. Millennium Development Goal. (2016). Improve Maternal Health. Retrieved from http://www.mdgmonitor.org/mdg-5-improve-maternal-health/ Accessed on 24-oct-2017 
16. Anastasi, E., Borchert, M., Campbell, O.M.R., Sondorp, E., Kaducu, F., Hill, O., Okeng, D., Odong, V.N., Lange, I.L. (2015). Losing Women along The Path to Safe Motherhood: Why Is There a Gap between Women's Use of Antenatal Care and Skilled Birth Attendance? A Mixed Method Study in Uganda. BMC Pregnancy and Childbirth. 15:287

17. Uganda Bureau of Statistics (UBOS) and ICF International. (2012). Demographic and Health Survey 2011, Kampala, Uganda: UBOS; and Calverton, MD, USA: ICF International, 2012

18. Mwania N. (2015). The Importance of Baseline/Socio-Economic Survey for Project in Kenya.

19. Ekirapa-Kiracho E, Tetui M, Bua J. (2017). Maternal and neonatal Implementation for equitable systems. A study design paper. Glob Health Action. 2017; 10:1346925

20. Kiberu VM, Mars M, Scott RE. (2017). Barriers and Opportunities to Implementation of Sustainable E-Health Programmes in Uganda: A Literature Review. African Health Journal of Primary Health Care \& Family Medicine. 2017; 9(1): 1277

21. Shahabuddin A, Stlinger CN, Delvaux T, Sarker M, Delamou A, Bardajõ A, Broerse JEW, Brouwere V. (2017). Exploring Maternal Health Care-Seeking Behavior of Married Adolescent Girls in Bangladesh: A Social-Ecological Approach. PLoS ONE 12(1).

22. World Health Organization. (2015b). Improve Maternal Health.

Retrieved from http://www.who.int/mediacentre/factsheets/fs348/en/ on 25 th Nov 2015

23. Ganley JK, Obeng B, Segbefia AY., Mwinyuri V, Yeboah JY, \& Baatiema L. (2015). How intra-familial decision-making affects women's access to and use of maternal healthcare services in Ghana: a qualitative study. BMC Pregnancy and childbirth. 15:173 DOI $10.1186 / \mathrm{s} 12884-015-0590-4$.

24. Kawungezi PC, Akii Bua D, Aleni C, Chitayi M, Niwaha Anxious, Kazibwe A, Sunya E, Mumbere EW, Mutesi C, Tukei C, Kasangaki A. \& Nakubulwa S. (2015). Attendance and 
Utilization of Antenatal Care (ANC) Services: Multi-Center Study in Upcountry Areas of Uganda. Open J Prev Med. 2015 March 1; 5(3): 132-142. doi:10.4236/ojpm.2015.53016.

25. Byomire G. \& Maiga G. (2015). Adoption and Use of Mobile Phones for Maternal Healthcare Service Delivery. Institute for Computer Sciences, Social Informatics and Telecommunications Engineering 2015 A. Nungu et al. (Eds.): AFRICOMM 2014, LNICST 147, pp. 103-114, 2015DOI: 10.1007/978-3-319-16886-9_11

26. Rutaremwa G, Wandera OS, Jhamba T, Akiror E and Kiconco A. (2015). Determinants of maternal health services utilization in Uganda. BMC Health Services Research. 15:271

27. Abekar-Nkrumah G, Guerriero M, \& Purohit O. (2014). ICT's and Maternal Healthcare Utilization. Evidence from Ghana. International Journal for Social Economics, Vol 41 Issue:7, pp. 518-541

28. Kabakyenga JK., Östergren P, Turyakira E, \& Pettersson KOP (2011). Knowledge of Obstetric Danger Signs and Birth Preparedness Practices among Women in Rural Uganda. 29. Isabalija SR, Mayoka KG, Rwashana AS, Mbarika VW. (2011). Factors Affecting Adoption, Implementation and Sustainability of Telemedicine Information Systems in Uganda. Journal of Health Informatics in Developing Countries.

30. Lee ACC, Lawn JE, Cousens S, Kumar V, Osrin D, Bhutta ZA, Wall SN., Nandakumar AK, Syed U, Darmstadt GL. (2009). Linking families and facilities for care at birth: What works to avert intrapartum-related deaths? International Journal of Gynaecology and Obstetrics. doi: 10.1016/j.ijgo.2009.07.016

31. Kyomuhendo GB. (2003). Low Use of Maternal Services in Uganda: Impact of Women's Status, Traditional Beliefs and Limited Resources. Reproductive Health Matters, 11(21), $16-26$

32. World Health Organization. (2015a). Improve Maternal Health. 
bioRxiv preprint doi: https://doi.org/10.1101/557413; this version posted February 22, 2019. The copyright holder for this preprint (which was not certified by peer review) is the author/funder, who has granted bioRxiv a license to display the preprint in perpetuity. It is made available under aCC-BY 4.0 International license.

Retrieved

from

http://www.who.int/topics/millennium development goals/maternal health/en/ on $11^{\text {th }}$ Aug 2015

33. Namatovu, HK. (2018). Enhancing Antenatal Care Decisions among Expectant Mothers in Uganda. ISBN 978-94-034-0569-8. PhD Thesis, University of Groningen, Netherlands. Available: https://www.rug.nl/research/portal/files/56325553/Complete thesis.pdf 
Table 1: Demographics

\begin{tabular}{|c|c|c|c|}
\hline \multirow[t]{2}{*}{ Number that participated and returned questionnaires } & \multicolumn{2}{|c|}{$\begin{array}{c}\text { Number/Percent of } \\
\text { Mothers } \\
\mathrm{N}=164\end{array}$} & \multirow[t]{2}{*}{ Total } \\
\hline & Kampala & Jinja & \\
\hline Number of Respondents & 83 & 81 & 164 \\
\hline Households visited & $175(54.6 \%)$ & $145(45.4 \%)$ & $320(100 \%)$ \\
\hline \multicolumn{4}{|l|}{ Education Level } \\
\hline Primary & 19(11.7\%) & $35(21.5 \%)$ & $54(33.1 \%)$ \\
\hline Secondary & $28(17.2 \%)$ & $31(19 \%)$ & $59(36.2 \%)$ \\
\hline Vocational & $17(10.4 \%)$ & $2(1.2 \%)$ & $19(11.7 \%)$ \\
\hline University & $18(11 \%)$ & $13(8 \%)$ & $31(19 \%)$ \\
\hline \multicolumn{4}{|l|}{ Age Group } \\
\hline $18-25$ years & $30(18.3 \%)$ & $52(31.7 \%)$ & $82(50 \%)$ \\
\hline $26-35$ years & $38(23.2 \%)$ & $20(12.2 \%)$ & $58(35.4 \%)$ \\
\hline $36-45$ years & $12(7.3 \%)$ & $7(4.3 \%)$ & $19(11.6 \%)$ \\
\hline $46-50$ years & $3(1.8 \%)$ & $2(1.2 \%)$ & $5(3 \%)$ \\
\hline \multicolumn{4}{|l|}{ Status } \\
\hline Pregnant & $23(14 \%)$ & $19(11.6 \%)$ & $42(25.6 \%)$ \\
\hline Mother with baby less than two years & $60(36.6 \%)$ & $62(37.8 \%)$ & $122(74.4 \%)$ \\
\hline \multicolumn{4}{|l|}{ Parity } \\
\hline None & $7(4.3 \%)$ & $5(3 \%)$ & $12(7.3 \%)$ \\
\hline One & $14(8.5 \%)$ & $12(7.3 \%)$ & $26(15.9 \%)$ \\
\hline Two & $27(16.5 \%)$ & $38(23.2 \%)$ & $65(39.5 \%)$ \\
\hline Three & $22(13.4 \%)$ & $18(11 \%)$ & $40(24.4 \%)$ \\
\hline Four and above & $13(7.9 \%)$ & $8(4.9 \%)$ & $21(12.8 \%)$ \\
\hline \multicolumn{4}{|l|}{ Marital Status } \\
\hline Married or co-habiting & $63(38.4 \%)$ & $69(42 \%)$ & $132(80.4 \%)$ \\
\hline Staying Single & $20(12.4 \%)$ & $12(7.2 \%)$ & $32(19.6 \%)$ \\
\hline \multicolumn{4}{|l|}{ Working Status } \\
\hline Working with income & $29(17.6 \%)$ & $38(23.1 \%)$ & $67(40.7 \%)$ \\
\hline Not working & $54(33 \%)$ & $43(26.3 \%)$ & $97(59.3 \%)$ \\
\hline \multicolumn{4}{|l|}{ Household Heads } \\
\hline Male & $138(43.2 \%)$ & $105(32.7 \%)$ & $243(75.9 \%)$ \\
\hline Female & $37(11.6)$ & $40(12.5 \%)$ & $77(24.1 \%)$ \\
\hline \multicolumn{4}{|l|}{$\begin{array}{l}\text { Households within } 5 \mathrm{~km} \text { distance or more from a } \\
\text { health facility }\end{array}$} \\
\hline Nearest public health facility & $78(24.5 \%)$ & $73(22.8 \%)$ & $151(47.3 \%)$ \\
\hline Nearest private health facility & $97(30.2 \%)$ & $72(22.5 \%)$ & $169(52.7 \%)$ \\
\hline
\end{tabular}


bioRxiv preprint doi: https://doi org/10.1101/557413. this version posted February 22, 2019. The copyright holder for this preprint (which was not certified by peer review) is the author/funder, who has granted bioRxiv a license to display the preprint in perpetuity. It is made available under aCC-BY 4.0 International license.

Table 2: Reproductive health information of expectant mothers

\begin{tabular}{|c|c|c|c|c|c|c|}
\hline \multirow{2}{*}{$\begin{array}{l}\text { Respondents } \\
\text { that returned } \\
\text { questionnaire } \\
\mathrm{S}\end{array}$} & \multicolumn{5}{|c|}{ Number/Percent of Mothers N=164 } & \multirow[t]{2}{*}{ Total } \\
\hline & \multicolumn{5}{|c|}{ Parity } & \\
\hline & None & 1 & 2 & 3 & $>=4$ & \\
\hline Education & & & & & & \\
\hline Primary & $5(3.1 \%)$ & $7(4.3 \%)$ & $26(16 \%)$ & $12(7.4 \%)$ & $4(2.5 \%)$ & $54(33.1 \%)$ \\
\hline Secondary & $3(1.5 \%)$ & $10(6.1 \%)$ & $18(11 \%)$ & $16(9.8 \%)$ & $12(7.4 \%)$ & $59(36.2 \%)$ \\
\hline Vocational & $4(2.5 \%)$ & $2(1.2 \%)$ & $6(3.7 \%)$ & $6(3.7 \%)$ & $1(0.6 \%)$ & $19(11.7 \%)$ \\
\hline University & $0(0 \%)$ & $7(4.3 \%)$ & $14(8.6 \%)$ & $6(3.7 \%)$ & $4(2.5 \%)$ & $31(19 \%)$ \\
\hline Age & & & & & & \\
\hline $18-25$ & $9(5.5 \%)$ & $15(9.1 \%)$ & $43(26.2 \%)$ & $15(9.1 \%)$ & $0(0 \%)$ & $82(50 \%)$ \\
\hline $26-35$ & $3(1.8 \%)$ & $9(5.5 \%)$ & $17(10.4 \%)$ & $16(9.8 \%)$ & $13(7.9 \%)$ & $58(35.4 \%)$ \\
\hline $36-45$ & $0(0 \%)$ & $2(1.2 \%)$ & $4(2.4 \%)$ & $7(4.3 \%)$ & $6(3.7 \%)$ & $19(11.6 \%)$ \\
\hline $46-50$ & $0(0 \%)$ & $0(0 \%)$ & $1(0.6 \%)$ & $2(1.2 \%)$ & $2(1.2 \%)$ & $5(3 \%)$ \\
\hline $\begin{array}{l}\text { Marital } \\
\text { Status }\end{array}$ & & & & & & \\
\hline Yes & $10(6.1 \%)$ & $21(12.8 \%)$ & $53(32.3 \%)$ & $32(19.5 \%$ & $16(9.8 \%)$ & $132(80.5 \%)$ \\
\hline No & $2(1.2 \%)$ & $5(3 \%)$ & $12(7.3 \%)$ & $8(4.9 \%)$ & $5(3 \%)$ & $32(19.5 \%)$ \\
\hline
\end{tabular}


bioRxiv preprint doi: https://doi.org/10.1101/557413; this version posted February 22, 2019. The copyright holder for this preprint (which was not certified by peer review) is the author/funder, who has granted bioRxiv a license to display the preprint in perpetuity. It is made available under aCC-BY 4.0 International license.

Table 3: Marital Status and age

\begin{tabular}{|c|c|c|c|c|c|}
\hline & & \multicolumn{3}{|c|}{ Number/Percent of Mothers N=164 } & \multirow[t]{2}{*}{ Total } \\
\hline $\begin{array}{l}\text { Respondents } \\
\text { that returned } \\
\text { questionnaires }\end{array}$ & \multicolumn{4}{|c|}{ Age (Years) } & \\
\hline & $18-25$ & $26-35$ & $36-45$ & $46-50$ & \\
\hline \multicolumn{6}{|l|}{ Marital Status } \\
\hline Yes & $68(41.5 \%)$ & $42(25.6 \%)$ & $17(10.4 \%)$ & $5(3 \%)$ & $132(80.5 \%)$ \\
\hline No & $14(8.5 \%)$ & $16(9.8 \%)$ & $2(1.2 \%)$ & $0(0 \%)$ & $32(19.5 \%)$ \\
\hline
\end{tabular}


bioRxiv preprint doi: https://doi.org/10.1101/557413; this version posted February 22, 2019. The copyright holder for this preprint (which was not certified by peer review) is the author/funder, who has granted bioRxiv a license to display the preprint in perpetuity. It is made available under aCC-BY 4.0 International license.

Table 4: Test of Independence between the Predictor and Response Variable

\begin{tabular}{llccc}
\hline $\begin{array}{l}\text { Predictor } \\
\text { Variable }\end{array}$ & Response Variable & $\begin{array}{l}\text { Degree of } \\
\text { Freedom }\end{array}$ & $\begin{array}{l}\text { Pearson's Chi- } \\
\text { Square }\end{array}$ & $\begin{array}{l}\text { Asymp. Sig } \\
\text { Value }\end{array}$ \\
\hline Age & Parity & 12 & 38.15 & 0.000 \\
Education & Parity & 12 & 17.80 & 0.122 \\
Age & Education & 9 & 35.12 & 0.000 \\
Age & Marital Status & 3 & 4.90 & 0.179 \\
Education & Marital Status & 3 & 3.14 & 0.371 \\
Education & Decision Making Autonomy & 3 & 8.63 & 0.035 \\
Age & Decision Making Autonomy & 3 & 8.81 & 0.032 \\
Parity & Decision Making Autonomy & 4 & 4.29 & 0.368 \\
Marital Status & Decision Making Autonomy & 1 & 4.10 & 0.043 \\
\hline
\end{tabular}


Table 5: Antenatal care and decision-making practices of expectant mothers

\begin{tabular}{|c|c|c|c|}
\hline \multirow{2}{*}{$\begin{array}{l}\text { Number that participated and returned } \\
\text { questionnaires }\end{array}$} & \multicolumn{2}{|c|}{$\begin{array}{l}\text { Number/Percent of Mothers } \\
\qquad N=164\end{array}$} & Total \\
\hline & Kampala & Jinja & \\
\hline \multicolumn{4}{|l|}{ Major source of ANC information } \\
\hline Peer Mothers & $9(5.7 \%)$ & $22(14 \%)$ & $31(19.7 \%)$ \\
\hline Midwives & $39(24.8 \%)$ & $20(12.7 \%)$ & $59(37.6 \%)$ \\
\hline Family and Friends & $6(3.8 \%)$ & $1(0.6 \%)$ & $7(4.5 \%)$ \\
\hline Village health teams & $19(12.1 \%)$ & $36(22.9 \%)$ & $55(35.0 \%)$ \\
\hline My experience & $4(2.5 \%)$ & $1(0.6 \%)$ & $5(3.2 \%)$ \\
\hline \multicolumn{4}{|l|}{ Information aiding decision making } \\
\hline Nutritional Information & $2(1.2 \%)$ & $3(1.8 \%)$ & $5(3.0 \%)$ \\
\hline Lab test results & $9(5.5 \%)$ & $2(1.2 \%)$ & $11(6.7 \%)$ \\
\hline Blood pressure check-ups results/symptoms & $5(3.0 \%)$ & $2(1.2 \%)$ & $7(4.3 \%)$ \\
\hline Immunization information & $6(3.7 \%)$ & $4(2.4 \%)$ & $10(6.1 \%)$ \\
\hline Information on Danger Signs & $9(5.5 \%)$ & $3(1.8 \%)$ & $12(7.3 \%)$ \\
\hline Info. on types of services offered & $7(4.3 \%)$ & $3(1.8 \%)$ & $10(6.1 \%)$ \\
\hline All the above & $4(2.4 \%)$ & $9(5.5 \%)$ & $13(7.9 \%)$ \\
\hline Not sure & $31(18.9 \%)$ & $47(28.7 \%)$ & $78(47.6 \%)$ \\
\hline \multicolumn{4}{|l|}{ Decision making autonomy } \\
\hline Yes & $41(25.2 \%)$ & $25(15.3 \%)$ & $66(40.5 \%)$ \\
\hline No & $41(25.2 \%)$ & $56(34.4 \%)$ & $97(59.5 \%)$ \\
\hline \multicolumn{4}{|l|}{ Who makes your decisions } \\
\hline Spouse & $12(14.6 \%)$ & $19(23.2 \%)$ & $31(37.8 \%)$ \\
\hline Midwife & $15(18.3 \%)$ & $3(3.7 \%)$ & $18(22 \%)$ \\
\hline Peer mothers & $2(2.4 \%)$ & $5(6.1 \%)$ & $7(8.5 \%)$ \\
\hline Village health teams & $13(15.9 \%)$ & $13(15.9 \%)$ & $26(31.7 \%)$ \\
\hline \multicolumn{4}{|l|}{ Why don't you make ANC decisions } \\
\hline I do not know much about ANC & $16(16.5 \%)$ & $32(33 \%)$ & $48(49.5 \%)$ \\
\hline My husband provides the money & $14(14.4 \%)$ & $17(17.5 \%)$ & $31(32 \%)$ \\
\hline I do not know & $7(7.2 \%)$ & $5(5.2 \%)$ & $12(12.4 \%)$ \\
\hline I cannot make good decisions & $2(2.1 \%)$ & $1(1 \%)$ & $3(3.1 \%)$ \\
\hline It's my culture & $2(2.1 \%)$ & $1(1 \%)$ & $3(3.1 \%)$ \\
\hline \multicolumn{4}{|l|}{ Challenges prohibiting ANC access } \\
\hline Lack of information about ANC services & $36(22 \%)$ & $31(18.9 \%)$ & $67(40.9 \%)$ \\
\hline Lack of money & $13(7.9 \%)$ & $11(6.7 \%)$ & $24(14.6 \%)$ \\
\hline Long distances & $5(3 \%)$ & $16(9.8 \%)$ & $21(12.8 \%)$ \\
\hline Inadequate and poor services at hospitals & $26(15.9 \%)$ & $17(10.4 \%)$ & $43(26.2 \%)$ \\
\hline Cultural Inclination & $2(1.2 \%)$ & $6(3.77 \%)$ & $8(4.9 \%)$ \\
\hline None of the above & $1(0.6 \%)$ & $0(0 \%)$ & $1(0.6 \%)$ \\
\hline \multicolumn{4}{|l|}{ Previous ANC attendance } \\
\hline Yes & $59(37.8 \%)$ & $29(18.6 \%)$ & $88(56.4 \%)$ \\
\hline No & $23(14.7 \%)$ & $45(28.8 \%)$ & $68(43.6 \%)$ \\
\hline \multicolumn{4}{|l|}{ Mothers with mobile phones } \\
\hline Yes & $62(38 \%)$ & $67(41.1 \%)$ & $129(79.1 \%)$ \\
\hline No & $21(12.9 \%)$ & $13(8 \%)$ & $34(20.9 \%)$ \\
\hline \multicolumn{4}{|l|}{ Access to ANC services using any ICT's } \\
\hline Yes & $9(5.5 \%)$ & $6(3.7 \%)$ & $15(9.2 \%)$ \\
\hline No & $74(45.4 \%)$ & $74(45.4 \%)$ & $148(90.8 \%)$ \\
\hline
\end{tabular}




\section{Legend to Figures}

Figure 1. Study area map showing locations of study sites, healthcare centers and access.

Figure 2. Technologies used to access ANC

Figure 3. ICT services aiding ANC

Figure 4. Other uses of mobile phones

Figure 5. Barriers limiting uptake of ICT 


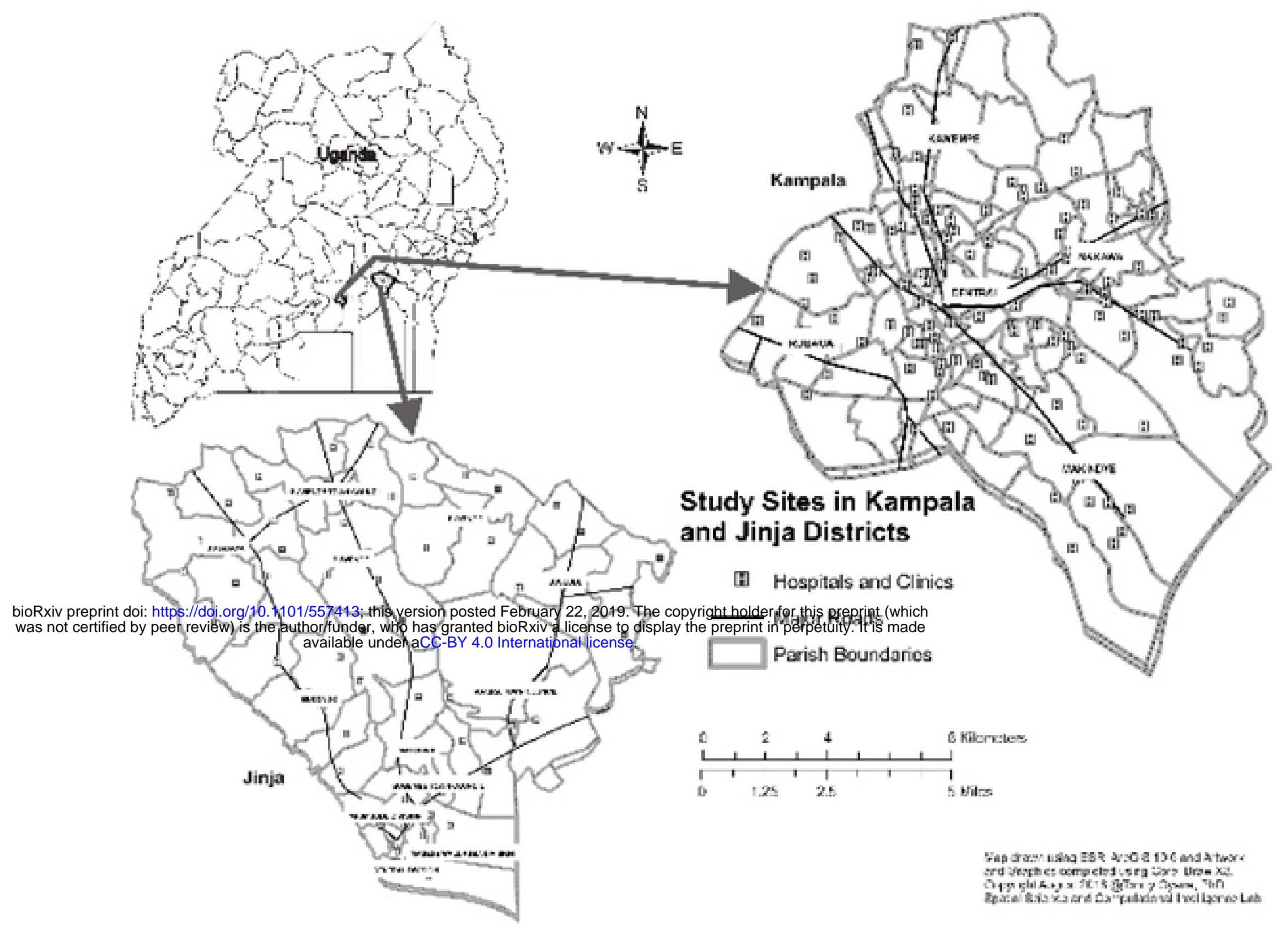

Figure 1: Study area map showing locations of study sites, healthcare centers and access.

Figure 1 


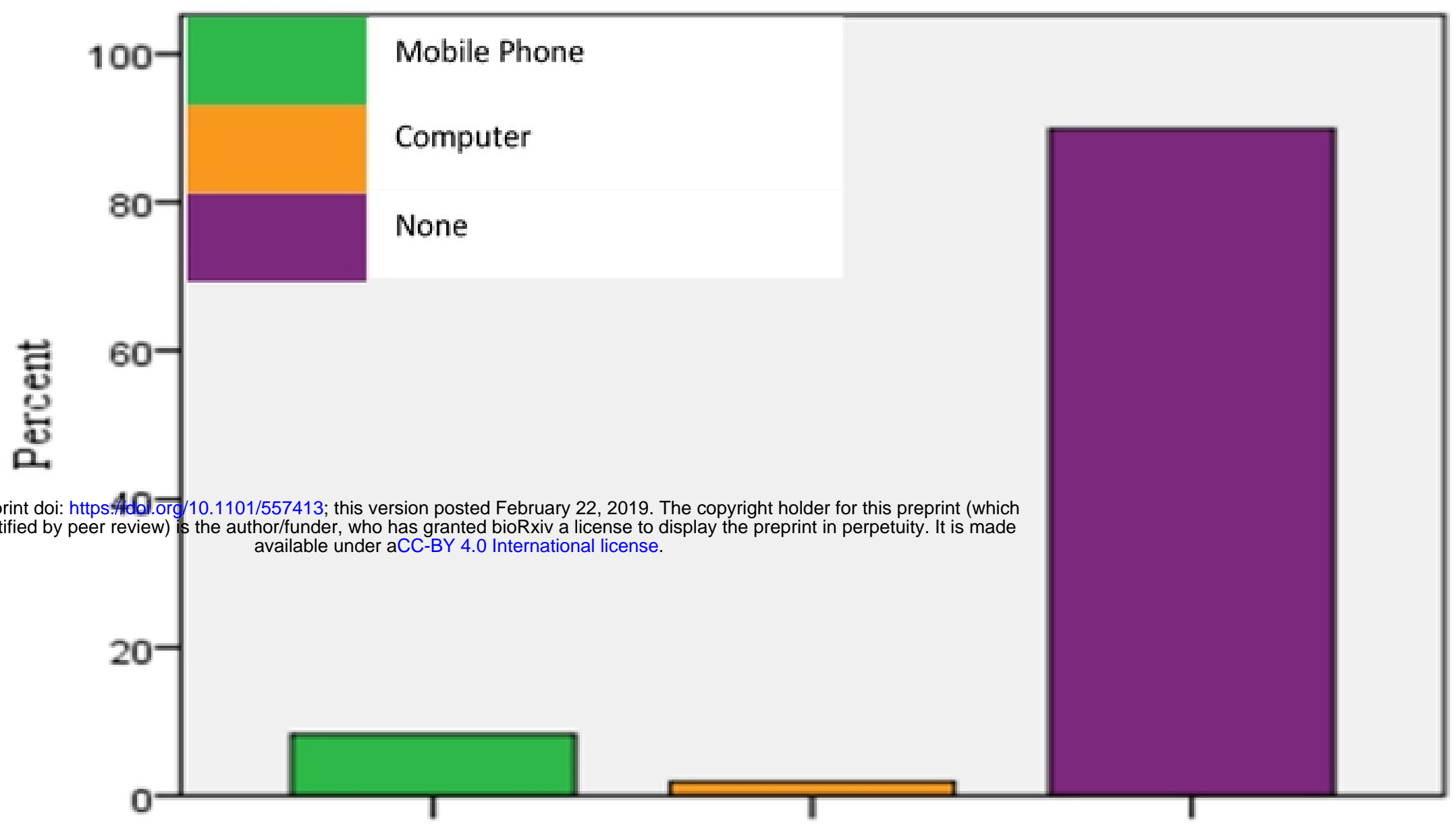

Figure 2: Technologies used to access ANC 

bioRxiv preprint doi: https://doi.org/10.1101/557413; this version posted February 22, 2019. The copyright holder for this preprint (which
was not certified by peer review) is the author/funder, who has granted bioRxiv a license to display the preprint in perpetuity. It is made available under $\mathrm{CCC}-\mathrm{BY} 4.0$ International license. 


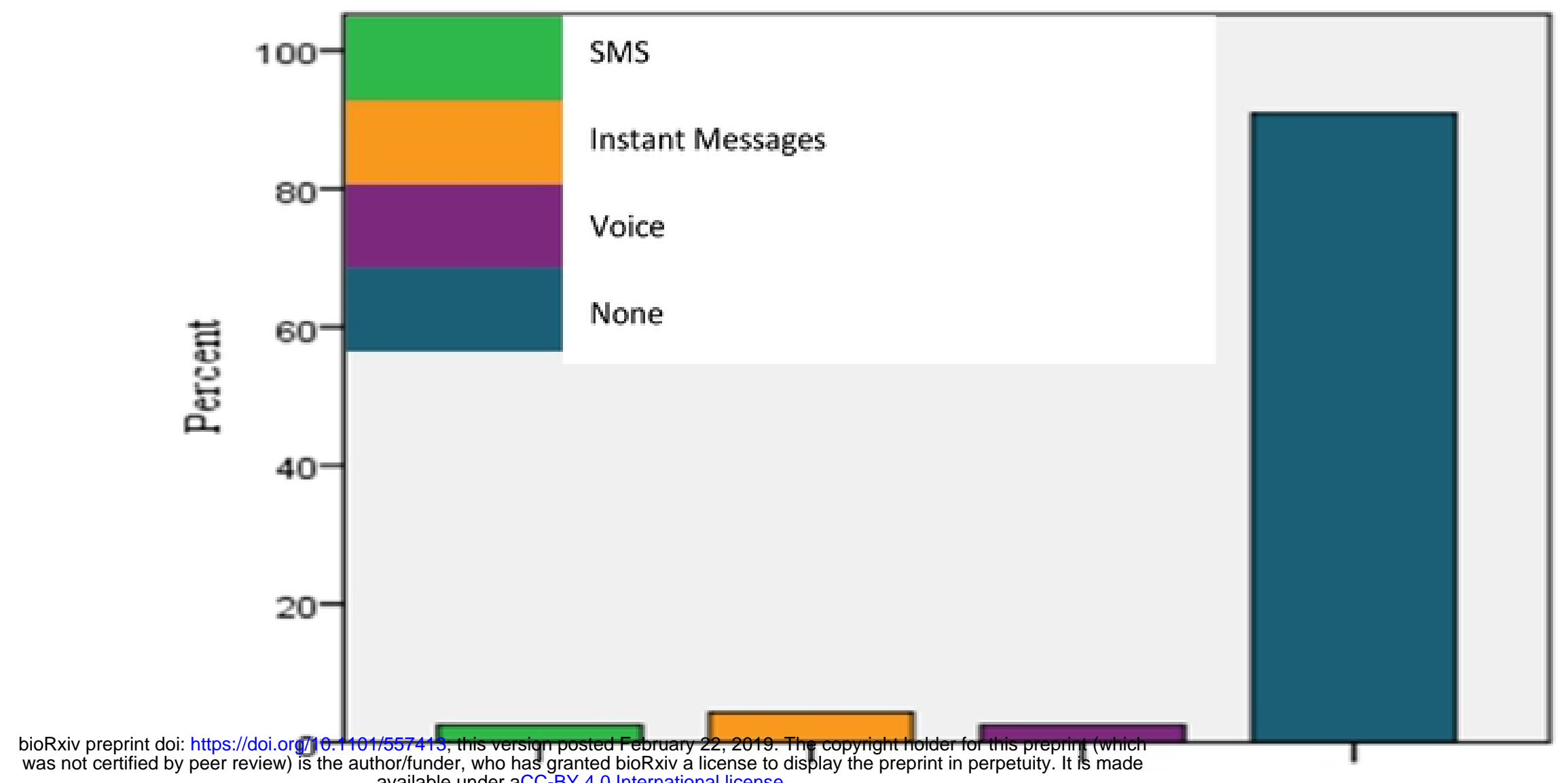

was not certified by peer review) is the author/funder, who has granted bioRxiv a license to display the preprint in perpettuity. It its made

Figure 3: ICT services aiding ANC

Figure 3 


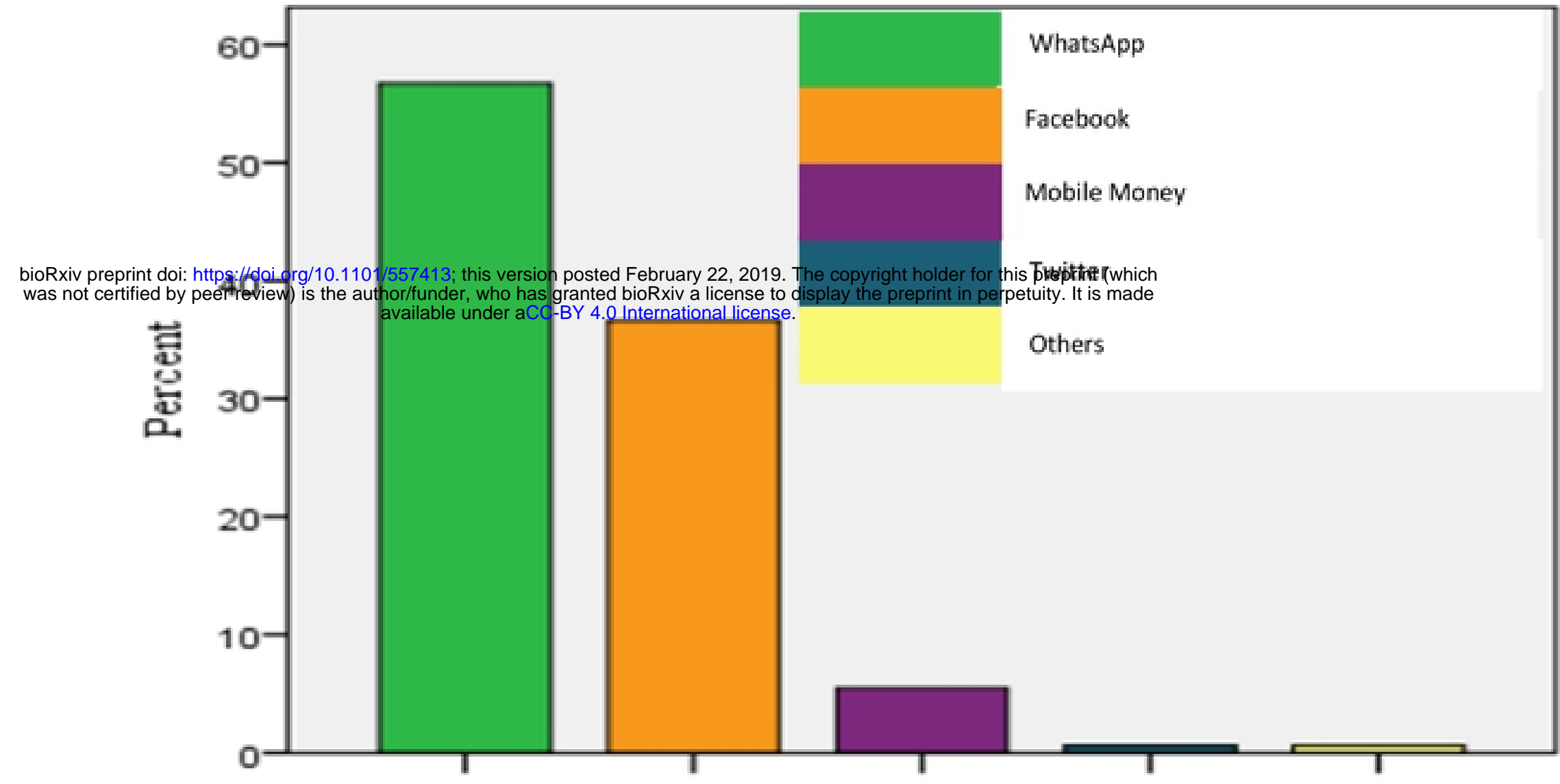

Figure 4: Other uses of mobile phones

Figure 4 


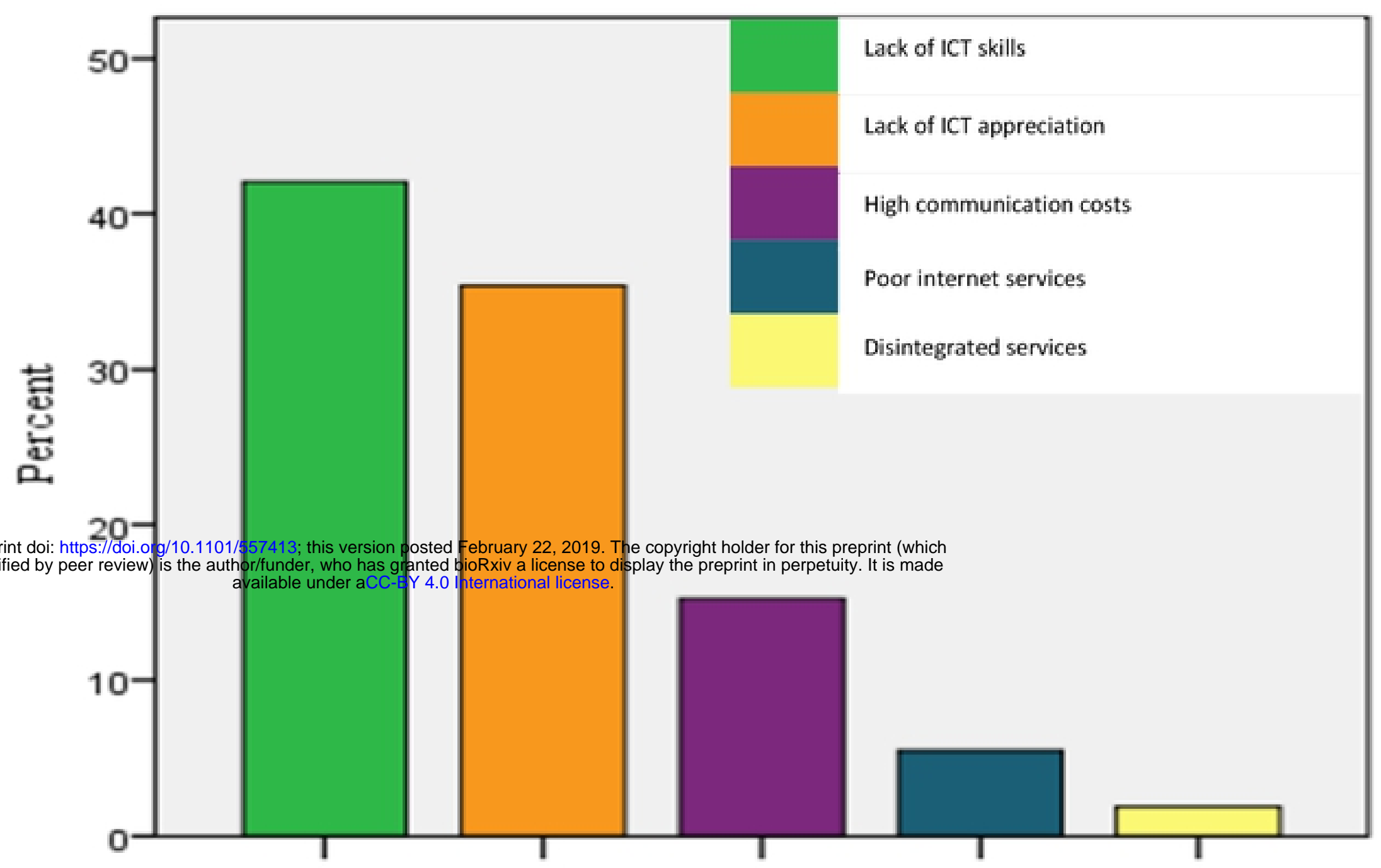

Figure 5: Barriers limiting uptake of ICT

Figure 5 